\title{
Impact on the phased abolition of co-payments on the utilisation of selected prescription medicines in Wales
}

Alam, M.F.; Cohen, D.; Dunstan, Frank; Hughes, Dyfrig; Routledge, P.A.

\section{Health Economics}

DOI:

10.1002/hec.3530

Published: 01/01/2018

Peer reviewed version

Cyswllt i'r cyhoeddiad / Link to publication

Dyfyniad o'r fersiwn a gyhoeddwyd / Citation for published version (APA):

Alam, M. F., Cohen, D., Dunstan, F., Hughes, D., \& Routledge, P. A. (2018). Impact on the phased abolition of co-payments on the utilisation of selected prescription medicines in Wales. Health Economics, 27(1), 236-243. https://doi.org/10.1002/hec.3530

\section{Hawliau Cyffredinol / General rights}

Copyright and moral rights for the publications made accessible in the public portal are retained by the authors and/or other copyright owners and it is a condition of accessing publications that users recognise and abide by the legal requirements associated with these rights.

- Users may download and print one copy of any publication from the public portal for the purpose of private study or research.

- You may not further distribute the material or use it for any profit-making activity or commercial gain

- You may freely distribute the URL identifying the publication in the public portal ?

Take down policy

If you believe that this document breaches copyright please contact us providing details, and we will remove access to the work immediately and investigate your claim. 


\title{
IMPACT OF THE PHASED ABOLITION OF CO-PAYMENTS ON THE UTILISATION OF SELECTED PRESCRIPTION MEDICINES IN WALES
}

KEYWORDS: co-payment, price-elasticity, dispensing, difference-in-difference

\begin{abstract}
We have taken advantage of a natural experiment to measure the impact of the phased abolition of prescription co-payments in Wales. We investigated three study periods covering the phased abolition: from $£ 6$ to $£ 4, £ 4$ to $£ 3$ and $£ 3$ to $£ 0$. A difference-in-difference modelling was adopted and applied to monthly UK general practice level dispensing data on 14 selected medicines which had the highest percentage of items dispensed subject to a co-payment prior to abolition. Dispensing from a comparator region (North East of England) with similar health and socio-economic characteristics to Wales, and where prescription co-payments continued during the study periods, were used to isolate any non-price effects on dispensing in Wales. Results show a small increase in dispensing of 14 selected medicines versus the comparator. Compared with NE England, monthly average Welsh dispensing was increased by 11.93 items (7.67\%; $95 \%$ CI: $7.2 \%$ to $8.1 \%), 6.37$ items (3.38\%; 95\% CI: $2.9 \%$ to $3.7 \%)$ and 9.18 items (4.54\%; $95 \%$ CI: $4.2 \%$ to $4.9 \%)$ per practice per 1000 population during the periods when copayment was reduced. Price elasticities of the selected medicines utilisation were $-0.23,-0.13$ and -0.04 in three analyses, suggesting the abolition of co-payment had small effect on Welsh dispensing.
\end{abstract}




\section{INTRODUCTION}

Globally, there has been a substantial growth in government health expenditure due to increased health care costs (Dieleman et al., 2016). To offset some of these costs, co-payment systems have been an aspect of healthcare in many countries (Austvoll-Dahlgren et al., 2008), including the UK, where co-payment for prescription medicines has been in the form of a flat fee per item dispensed to NHS patients.

A unified approach to prescription co-payment had been applied across all parts of the UK (England, Wales, Scotland and Northern Ireland) up to 2000 when the Welsh Assembly Government froze the co-payment at its then current level of $£ 6$ per item. A phased reduction began in October 2004, with abolition in April 2007. During this period, the co-payment increased steadily in nominal terms in other parts of the UK, but in real terms was virtually constant.

$<$ Figure I here>

Assessment of the effects of the Welsh policy provided two unique opportunities. First, whereas all previous studies in the UK and most other countries examined the effects of increasing costs to patients, the new Welsh policy allowed examination of the effects of reducing and ultimately abolishing them. Second, the Welsh policy provided a natural experiment which, for the first time, allowed a comparison of dispensing rates between a geographical area which experienced a significant change in the co-payment with another where it remained broadly constant after taking account of inflation. 
The international literature consistently shows that an increase in co-payment leads to a decrease in the probability of prescription use, the number of drugs utilised and prescription drugs expenditures (Goldman et al., 2007; Leibowitz et al., 1985; McManus et al., 1996; Tamblyn et al., 2001; Lexchin and Grootendorst, 2004). Price elasticity of utilisation is a common, unitless measure which describes the responsive of demand for prescription medicines (Gemmill et al., 2008). The relationship between co-payment and drug utilization can be seen in reviews by Barnieh et al. (2013), Gemmill et al. (2008) and Gibson et al. (2005). Several previous studies have estimated the price elasticity of prescription medicines utilisation in the UK mainly using national-level, aggregated dispensing data and producing price elasticity estimates ranging from -0.64 to -0.09 (Ryan and Birch, 1991; Lavers, 1989; Hughes and McGuire, 1995; O’Brien, 1989). While estimates from other countries are mainly in line with this (Puig-Junoy, 1988; Van Vliet, 1999; Smith, 1993; Motheral and Henderson, 1999; Klick and Stratmann, 2005; Street et al., 1999; Fiorio and Siciliani, 2010; Grootendorst and Levine, 2001), there remains significant heterogeneity, since the type of data used, method of analysis applied, subpopulations considered and other factors vary across studies (Gemmill et al., 2008).

Although in the UK prescriptions for certain medical conditions are exempt from copayment, most exemptions relate to individuals regardless of their condition. These include inter alia older people, children, pregnant women, NHS in-patients and those receiving various forms of income support. As a result approximately half the UK population has always been exempt from co-payment (Walley, 1998). In 2003/4, 89\% of items dispensed in the community in Wales were not subject to co-payment (Health Solutions Wales, 2004). Any effect of policy changes on total dispensing would therefore be mitigated by the fact that dispensing of most medicines would be only minimally affected if at all. 
We aimed to estimate the relationship between changes in prescription co-payments and changes in dispensing rates in Wales during the period October 2003 to March 2008 focussing on those medicines which had the highest number of items dispensed with a co-payment prior to abolition as these are the ones most likely to be affected by any changes to co-payments.

\section{METHODS}

The utilisation of prescription medicines is clearly not solely a function of price and previous studies have included a range of other variables including 'price of substitutes', 'sickness benefit', 'working population', etc. We avoided any assumptions of confounding effects by using North East England as a comparator area which closely resembles Wales in terms of key health and socioeconomic characteristics (Table I). Further, we surveyed all Health Boards in Wales and all Primary Care Trusts in NE England (essentially the bodies which receive funding to secure or provide health care to those living in defined geographical areas) to identify any differences in local prescribing policies and initiatives which could have differentially impacted on dispensing rates. Although there was evidence of some local factors that might have influenced dispensing rates, responses from both areas were broadly in accord (Cohen et al., 2010). We could therefore conclude that the influence on dispensing rates of all factors other than price was likely to be similar for the two areas over the period of study. <Table I here>

We selected the 14 medicines (strictly, 15 but with two strengths of amoxicillin; Table II) from a list of the 100 dispensed medicinal preparations that most frequently incurred a co- 
payment in Wales in April 2005. No medicine had more that 25\% of items dispensed subject to co-payment in Wales that year. A minimum percentage of items dispensed subject to copayment (4\%) was used to ensure representation of treatments for a range of conditions, both chronic and acute, and included products also available without prescription, although at reduced dose, under supervised sale at community pharmacies: omeprazole (10mg only), cocodamol (8mg codeine/500mg paracetamol only) and simvastatin (10mg only).

<Table II here >

GP practices in Wales were considered as being 'treated' by the changes in co-payment policy (intervention), while practices in NE England were not (control). We employed a difference-in-difference (DiD) approach (Cameron, 2005; Blundell and MaCurdy, 1999) to measure this effect. During the course of phased abolition, a total of four interventions took place: a reduction from $£ 6$ to $£ 5, £ 5$ to $£ 4, £ 4$ to $£ 3$ and $£ 3$ to $£ 0$. The second intervention (from $£ 5$ to $£ 4$ ) took place in April 2005 which was only six months after the first intervention in October 2004. The remaining two interventions occurred yearly thereafter. We considered a 12-month pre-intervention and 12-month post-intervention period. For consistency, we excluded the six month time window of the second intervention period (October 2004 to March 2005) from the analysis.

\subsection{ANALYSIS}

The econometric model is shown in equation (1) using 24 months practice-level time series dispensing data. The outcome, $Y_{\text {it }}$, measures the dispensing rate (number of items per 1000 population) dispensed by practice $i$ in month $t$, and is modelled as a function of practice fixed effects $\left(u_{i}\right)$ and time fixed effects $\left(v_{t}\right)$ and random error term with zero mean $\left(\varepsilon_{i t}\right)$. We define 
a variable $A R E A_{i t}$ which takes a value 1 if the practice is in Wales and another variable $I N T V_{i t}$ which equals 1 if the observation belongs to the period after the policy intervention.

$Y_{\mathrm{it}}=\alpha_{l}+u_{i}+v_{t}+w_{s}+\delta I N T V_{i t}+\lambda A R E A_{i t}+\gamma A R E A_{i t} * I N T V_{i t}+\varepsilon_{i t}$

The time fixed effects are months over two-year time-window that are represented by 23 dummy variables, with October 2003 being the reference category. The use of monthly dummies in model (1) accounts for time trends and their coefficients show how the mean dispensing rates change over time, conditional on practice effects. The model is also adjusted for season, $w_{s}$ (3 quarterly dummies, with 'October to December' being considered as the reference category and not included in the model). The coefficient of the interaction term, $\gamma$, indicates how dispensing rates differed between Wales and NE England in the last 12 months after the policy intervention, conditional on the practice and time effects.

The variance of a practice dispensing rate is inversely proportional to practice list size and these varied substantially between practices, hence model (1) is weighted by list size. The effect is to give more weight to large practices whose rates are likely to show smaller random fluctuations than small practices.

As a DiD approach assumes that trends in intervention and control areas are similar before introducing the intervention, we carried out a pre-trends test over 3 separate pre-intervention time periods $(1=$ October 2003 to September 2004, $2=$ April 2005 to March 2006, $3=$ April 2006 to March 2007) in line with Sutton et al. (2012), and given in equation (2).

$Y_{\mathrm{it}}=\alpha_{2}+u_{i}+\beta * t+\rho A R E A_{i t} * t+\varepsilon_{i t}$ 
where $t$ represents the month since the start of the data point, $\beta$ is an estimate of the monthly trend in NE England and $\rho$ is the difference in monthly trend between Wales and NE England. The null hypothesis is that $\rho=0$.

The regression models were estimated using a weighted least-square method, with robust standard error corrected for heteroscedasticity. A crude price elasticity of prescription medicines utilisation in Wales was then calculated using the formula,

Price elasticity $=\frac{\text { Percentage change in average medicines utilisation }}{\text { Percentage change in average prescription co-payment }}$

Since the study investigated interventions covering three time windows, our Analysis 1 covers a study period of two years when co-payment was $£ 6$ and $£ 4$, Analysis 2 covers a study period of two years when co-payment was $£ 4$ and $£ 3$ and, finally, Analysis 3 covers a study period of two years when co-payment was $£ 3$ and $£ 0$ in Wales.

The study received ethics approval from the South Wales Research Ethics Committee, reference 06/WSE02/31.

\section{DATA}

Health Solutions Wales (HSW) provided practice list size and practice-level monthly dispensing volume data for the 14 selected medicines, for all practices in Wales $(\mathrm{N}=485)$. The Prescription Pricing Authority (PPA) provided comparable data for all practices in NE England $(\mathrm{N}=393)$. We included all practices and months during October 2003 to September 2004 and April 2005 to March 2006 in our first analysis (analysis 1). Similarly, all practices and months during April 2005 to March 2007 are in analysis 2 and all practices and months during April 
2006 to March 2008 are in analysis 3, producing a total of 878 x $24=21,072$ observations in each analysis. The same sample of practices has been used in all three analyses. Table III provides descriptive statistics of dispensing and co-payment data for three analyses covering study periods defined in section 2 .

$<$ Table III here >

\section{RESULTS}

Results from pre-trends testing suggest that we were not able to reject the null hypothesis in all three analyses ( $\rho=0.43$ (95\% CI: -3.4 to 4.3$), \rho=0.84$ (95\% CI: -3.5 to 5.2$)$ and $\rho=1.4$ (95\% CI: -3.3 to 6.1) in Analyses 1, 2 and 3 respectively).

Table III shows that monthly dispensing of 14 selected medicines increased after the intervention in all three analyses and in both areas. However, the increase was greater in Wales than in NE England (33.1, 13.73 and 14.02 items (per practice per 1000 population) versus 21.21, 7.05 and 4.36 items in Analyses 1, 2 and 3 respectively.

The DiD model suggests that, compared to NE England, Welsh dispensing increased in all analyses $(\mathrm{p}<0.0001)$, however, the increase was smaller in Analysis 2 when co-payment was reduced to $£ 3$ from $£ 4$ (Table IV).

The 11.93 items (per practice per 1000 population) increase in Welsh dispensing of 14 selected medicines is equivalent to roughly $7.7 \%$ increase of the average Welsh dispensing 
during the period when prescription co-payment was $£ 6$ and $£ 4$ (Analysis 1 , Table V). Corresponding increases in Analyses 2 and 3 were $3.4 \%$ and $4.5 \%$, respectively.

We estimated a crude price elasticity of medicines utilisation as $-0.23,-0.13$ and -0.04 from Analyses 1, 2 and 3 respectively.

$<$ Tables IV and V here $>$

\section{DISCUSSION}

Our results suggest that the effect on dispensing of changing co-payment levels is not negligible. The Welsh policy was introduced with an explicit aim to improve health through removal of a (perceived) obstacle to those on low incomes obtaining the medicines they need (WAG, 2003). There is evidence that co-payment poses a barrier to adherence to treatment (Schafheutle, 2003). The increase in dispensing rates for the 14 selected medicines therefore suggests that there may have been a group of non-exempt patients in Wales who were not fully adherent with prescribed treatment before the policy was introduced. The policy may therefore have contributed to reducing patients' non-adherence which in principle should produce an increase in health. A separate study undertaken by the authors suggested that the Welsh policy did not have an impact on consumption of medicines available without prescription from pharmacies (Groves et al, 2010).

The price elasticity of utilisation estimates of $-0.23,-0.13$ and -0.04 for the three study periods respectively suggest that by the time the co-payment had fallen to a very low level (£3 
per item), much of the effect had already occurred and a further fall to zero (abolition) had a lesser impact on dispensing rates than the earlier reductions.

Our study suggests that the utilisation of prescription medicines in Wales is inelastic and implies that consumers are not particularly responsive to changes in co-payments at these levels. This is not uncommon for a tax-financed health care system such as that in the UK, suggesting that consumers in publicly funded health systems appear to be less sensitive to changes in out-of-pocket expenses than consumers in other types of insurance systems (Gemmill et al., 2008).

The low price elasticity estimates here may be due to several factors. Firstly, those patients whose utilisation is likely to be most sensitive to changes in price i.e. those on very low incomes, were already exempt from co-payment. Secondly, elasticity is commonly estimated for small changes in price; here the reductions happened in relatively large increments.

One advantage of our study was its ability to exploit a situation in which the policy on prescription co-payment changed in one area while remaining virtually constant in real terms in another with similar populations and local prescribing policies. Thus differences in dispensing could reasonably be assumed to be due to the Welsh policy on price. A disadvantage of our study, however, was the omission of the 6 month period when the prescription charged moved from $£ 5$ to $£ 4$, which may have coincided with the highest price elasticity of utilisation. There may also be unobserved confounding factors that were not controlled by comparison with the NE England. 


\section{CONCLUSIONS}

Abolition of co-payments has had a positive but small effect on dispensing rates in Wales. The magnitude of the impact of reductions in co-payment shown in this study appears to be broadly similar to those of increases in co-payment shown from previous studies. Use of a comparator area avoided the need to use questionable proxies to account for confounding variables but this approach is only possible in rare situations.

Disaggregating the data into three time periods showed most of the effect occurred in response to the earlier reductions from relatively high levels. The response to abolishing a copayment which has already fallen to a low level is less. Our study presents evidence that could support more detailed descriptions of underlying processes and qualitative analyses to help inform policy decisions.

\section{SOURCE OF FINANCIAL SUPPORT}

Wales Office for Research and Development in Health and Social Care (Project: ReF05/1/126)

\section{CONFLICT OF INTEREST}

The Authors have no conflict of interest. 


\section{ACKNOWLEDGEMENTS}

We are grateful to Dr. Susan Myles for her role in the early phases the study and to the members of the study Advisory Group (Prof. Tom Walley, Prof. Chris Brunsdon, Prof. Ceri Phillips and Dr. Mirella Longo). The authors alone are responsible for any errors or omissions in the present paper on the utilisation of selected prescription medicines in Wales.

\section{REFERENCES}

1. Austvoll-Dahlgren A, Aaserud M, Vist GE, Ramsay C, Oxman AD, Sturm H, Kösters JP, Vernby Å. 2008. Pharmaceutical policies: effects of cap and co-payment on rational drug use. Cochrane Database of Systematic Reviews Issue 1. Art. No.: CD007017.

2. Barnieh L, Clement F, Harris A et al. (2013): A Systematic Review of Cost-Sharing Strategies Used within Publicly-Funded Drug Plans in Member Countries of the Organisation for Economic Co-Operation and Development, PLOS One, 9 (3), e90434

3. Blundell R, MaCurdy T. 1999. Labour supply: a review of alternative approaches, In: Ashenfelter OC, Card D (Eds.), Handbook of Labour Economics North-Holland 3:1559 1695.

4. Cameron CA, Trivedi PK. 2005. Microeconometrics: Methods and Applications, New York: Cambridge University Press.

5. Cohen D, Alam MF, Dunstan FDJ, Myles S, Hughes DA, Routledge PA. 2010. Abolition of prescription co-payments in Wales: an observational study on dispensing rates, Value in Health 13(5):675-680.

6. Dieleman J, Templin T, Sadat N et al. 2016. National spending by source for 184 countries between 2013 and 2040, Lancet 387:2521-35 
7. Fiorio CV, Siciliani L. 2010. Co-payments and the demand for pharmaceuticals: Evidence from Italy, Economic Modelling 27:835-841.

8. Gemmill MC, Costa-Fon J, McGuire A. 2008. In search of a corrected prescription drug elasticity estimate: a meta-regression approach, Health Economics 16(6):627-643.

9. Gibson TB, Ozminkowski RJ, Goetzel RZ (2005) The effects of prescription drug cost sharing: a review of the evidence. American Journal of Managed Care, 11: 730740.

10. Goldman DP, Joyce GF, Zeng Y. 2007. Prescription drug cost sharing associations with medication and medical utilization and spending and health. The Journal of the American Medical Association 298(1):61-69.

11. Grootendorst P, Levine M. 2001. Do drug plans matter? Effects of drug plan eligibility on drug use among the elderly, Social Assistance Recipients and the General Population. Hamilton: McMaster University.

12. Groves S, Cohen D, Alam F, Mules S, Hughes D, Dunstan F, Routledge P. 2010. Abolition of prescription charges in Wales: The impact on medicine-use in those who used to pay. International Journal of Pharmacy Practice 18(6): 332-340.

13. Health Solutions Wales. Analysis of prescription items dispensed by exemption category, 2003-04, Prescribing Services Unit, UK NHS Wales.

14. Hughes D, McGuire A. 1995. Patient charges and utilisation of NHS prescription medicines: some estimates using cointegration procedure, Health Economics 4:213:220.

15. Klick J, Stratmann T. 2005. How sensitive are seniors to the price of prescription drugs? Florida State University College of Law Research Paper no. 161. 2005. Available at SSRN: http://ssrn.com/abstract=766844.

16. Lavers R. 1989. Prescription charges, the demand for prescriptions and morbidity. Applied Economics 21:1043-1052. 
17. Leibowitz A, Manning WG, Newhouse JP. 1985. The demand for prescription drugs as a function of cost sharing. Social Science and Medicine 21(10):1063-1069.

18. Lexchin J, Grootendorst P. 2004. Effects of prescription drug user fees on drug and health services use and on health status in vulnerable populations: a systematic review of the evidence. International Journal of Health Services 34(1):101-122.

19. McManus P, Donnelly N, Henry D, Hall W, Primrose J, Lindner J. 1996. Prescription drug utilization following patient co-payment changes in Australia. Pharmacoepidemiology and Drug Safety 5:385-392.

20. Motheral B, Henderson R. 1999. The effect of a copay increase on pharmaceutical utilisation, expenditures, and treatment continuation. American Journal of Managed Care $5: 1383-1394$.

21. O'Brien B. 1989. The effect of patient charges on the utilisation of prescription medicines. Journal of Health Economics. 8:109-132.

22. Puig-Junoy J. 1988. Gasto farmaceutico en Espana: effectos de la participacion del usario en el coste. Investigaciones Economicas 121:45-68 (in Spanish).

23. Ryan M, Birch S. 1991. Charging for health care: evidence on the utilisation of NHS prescribed drugs. Social Science and Medicine 33(6): 681-687.

24. Schafheutle E. 2003. Do high prescription charges undermine compliance? Pharmaceutical Journal 270:336-337.

25. Smith D. 1993.The effects of co-payments and generic substitution on the use and costs of prescription drugs. Inquiry 30:189-198.

26. Street A, Jones A, Furuta A. 1999. Cost-sharing and pharmaceutical utilisation and expenditure in Russia, Journal of Health Economics 18:459-472.

27. Sutton M, Nikolova S, Boaden R, et. al. 2012. Reduced mortality with hospital pay for performance in England, New England Journal of Medicine 367:1821-1828. 
28. Tamblyn R, Laprise R, Hanley JA, et al. 2001. Adverse events associated with prescription drug cost-sharing among poor and elderly persons, The Journal of the American Medical Association 285:421-429.

29. Van Vliet R, Van Doorslaer E, Van der Burg HG. 1999. Effecten van eigen betalingen op ziektekosten in Nederland. Tijdschrift voor Gezondheidswetenschappen 77: 397-405 (in Dutch).

30. Walley T. 1998. Prescription charges: change overdue? British Medical Journal 317: 487-488.

31. Welsh Assembly Government. 2003. Abolition of Prescription Charges - Report on Decision Taken by Minister of Health and Social Services. August 21, 2003. 


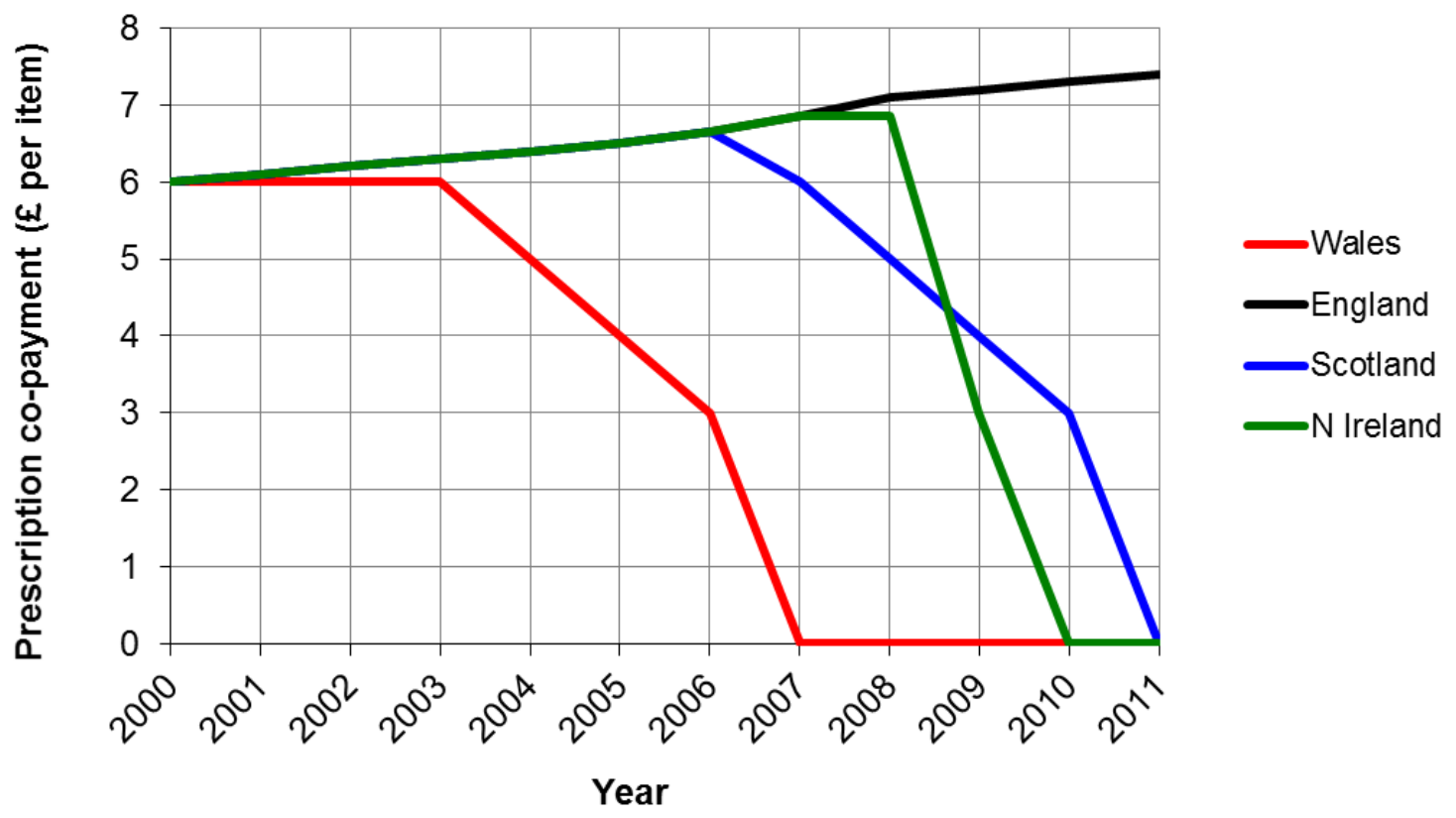

Figure 1. Per item prescription co-payment in Wales, England, Scotland and Northern Ireland: 2000- 2011 
Table I. Key health and economic statistics: Wales v NE England

\begin{tabular}{|l|c|c|}
\hline & Wales & NE England \\
\hline \% Reporting good health, 2001 & 65 & 64 \\
\hline \% Reporting not good health, 2001 & 12 & 12 \\
\hline Standardised Mortality Ratio, 2003 & 105 & 113 \\
\hline Life expectancy at birth - males, 2001 & 75.5 & 74.7 \\
\hline Life expectancy at birth - females, 2001 & 80.1 & 79.5 \\
\hline \% Population with limiting long term illness, 2001 & 23 & 23 \\
\hline \% Population with no qualifications, 2004 & 24 & 9 \\
\hline \% Population claiming income support & 8 & 6.2 \\
\hline Unemployment rate (\%), 2005 & 5.3 & 7 \\
\hline $\begin{array}{l}\text { \% Population claiming incapacity benefit/severe } \\
\text { disability rate }\end{array}$ & 7 & 610 \\
\hline Average weekly household total income (£) & 410 & 6 \\
\hline \% Population claiming disability allowance, 2002 & 7 & \\
\hline Source: Office for National Stistos, UK (2008) & & \\
\hline
\end{tabular}

Source: Office for National Statistics, UK (2008) 
Table II. Monthly number of items dispensed in Wales (14 selected medicines): April, 2005

\begin{tabular}{|c|c|c|c|}
\hline Medicine & Total & Exempt & Percentage Paid ${ }^{1}$ \\
\hline $\begin{array}{l}\text { Phenoxymethylpenicillin tablets } \\
\text { 250mg }\end{array}$ & 11,797 & 9,039 & 23.38 \\
\hline Amoxicillin capsules 500mg $(*)$ & 21,647 & 16,821 & 22.29 \\
\hline Erythromycin e/c tablets $250 \mathrm{mg}(* *)$ & 13,706 & 10,882 & 20.60 \\
\hline Diclofenac e/c tablets 50mg (**) & 17,342 & 13,851 & 20.13 \\
\hline Amoxicillin capsules $250 \mathrm{mg}(*)$ & 41,422 & 33,102 & 20.09 \\
\hline Citalopram tablets $20 \mathrm{mg}$ & 13,172 & 10,606 & 19.48 \\
\hline Fluoxetine capsules $20 \mathrm{mg}$ & 24,349 & 19,783 & 18.75 \\
\hline Trimethoprim tablets $200 \mathrm{mg}$ & 12,986 & 10,659 & 17.92 \\
\hline Co-codamol tablets $30 \mathrm{mg} / 500 \mathrm{mg}$ & 10,417 & 9,291 & 10.81 \\
\hline $\begin{array}{l}\text { Salbutamol inhaler } 100 \mathrm{mcg}(200 \\
\text { doses) }\end{array}$ & 32,914 & 29,384 & 10.72 \\
\hline Atenolol tablets $50 \mathrm{mg}$ & 45,454 & 40,660 & 10.55 \\
\hline Lansoprazole e/c capsules $15 \mathrm{mg}(* *)$ & 23,030 & 20,753 & 9.89 \\
\hline Omeprazole e/c capsules $20 \mathrm{mg}(* *)$ & 23,402 & 21,431 & 8.42 \\
\hline Bendroflumethiazide tablets $2.5 \mathrm{mg}$ & 83,094 & 76,571 & 7.85 \\
\hline Simvastatin tablets $20 \mathrm{mg}$ & 22,605 & 21,611 & 4.40 \\
\hline
\end{tabular}

Source: Health Solutions Wales (personal communication)

1. Number of items dispensed subject to co-payment/ Total number of items dispensed.

(*) The two strengths for amoxicillin were analysed separately but are considered a single medicine among the 14 medicines selected for this study.

$(* *) \mathrm{e} / \mathrm{c}=$ enteric coated 
Table III. Descriptive statistics of monthly dispensing items (per practice per 1000 population) and average co-payment

\begin{tabular}{|c|c|c|c|c|c|c|}
\hline & \multicolumn{6}{|c|}{ October 2003 to September 2004} \\
\hline & \multicolumn{3}{|c|}{ Wales } & \multicolumn{3}{|c|}{ NE England } \\
\hline & $\begin{array}{r}\text { No. of } \\
\text { observations }\end{array}$ & Mean & SD & $\begin{array}{r}\text { No. of } \\
\text { observations }\end{array}$ & Mean & SD \\
\hline Dispensing rate & 5820 & 155.54 & 42.15 & 4716 & 159.89 & 46.59 \\
\hline \multirow[t]{4}{*}{ Average co-payment } & 5820 & 5.99 & 0.01 & 4716 & 6.33 & 0.05 \\
\hline & \multicolumn{6}{|c|}{ April 2005 to March 2006} \\
\hline & \multicolumn{3}{|c|}{ Wales } & \multicolumn{3}{|c|}{ NE England } \\
\hline & $\begin{array}{r}\text { No. of } \\
\text { observations }\end{array}$ & Mean & SD & $\begin{array}{r}\text { No. of } \\
\text { observations }\end{array}$ & Mean & SD \\
\hline Dispensing rate & 5820 & 188.64 & 50.42 & 4716 & 181.10 & 51.91 \\
\hline \multirow[t]{4}{*}{ Average co-payment } & 5820 & 3.99 & 0.01 & 4716 & 6.49 & 0.02 \\
\hline & \multicolumn{6}{|c|}{ April 2006 to March 2007} \\
\hline & \multicolumn{3}{|c|}{ Wales } & \multicolumn{3}{|c|}{ NE England } \\
\hline & $\begin{array}{r}\text { No. of } \\
\text { observations }\end{array}$ & Mean & SD & $\begin{array}{r}\text { No. of } \\
\text { observations }\end{array}$ & Mean & SD \\
\hline Dispensing rate & 5820 & 202.37 & 53.34 & 4716 & 188.15 & 54.06 \\
\hline \multirow[t]{4}{*}{ Average co-payment } & 5820 & 2.99 & 0.01 & 4716 & 6.62 & 0.02 \\
\hline & \multicolumn{6}{|c|}{ April 2007 to March 2008} \\
\hline & \multicolumn{3}{|c|}{ Wales } & \multicolumn{3}{|c|}{ NE England } \\
\hline & $\begin{array}{r}\text { No. of } \\
\text { observations }\end{array}$ & Mean & SD & $\begin{array}{r}\text { No. of } \\
\text { observations }\end{array}$ & Mean & SD \\
\hline Dispensing rate & 5820 & 216.39 & 56.61 & 4716 & 192.51 & 56.55 \\
\hline Average co-payment & 5820 & 0.00 & 0.00 & 4716 & 6.83 & 0.03 \\
\hline
\end{tabular}

Note: Co-payment is deflated by monthly Retail Price Index. During a year, the total number of observations for 'Wales' is 5820 (all practices in Wales, $485 \times 12$ ) and the total number of observations for 'NE England' is 4716 (all practices in NE England, 393 x 12). 
Table IV. Difference-in-difference estimates, before and after introduction a change in copayment in Wales

\begin{tabular}{|l|c|c|c|}
\hline & $\begin{array}{c}\text { Difference-in- } \\
\text { difference }\end{array}$ & $\begin{array}{c}\text { 95\% Confidence } \\
\text { Interval }\end{array}$ & $p$-value \\
\hline Analysis 1 & $11.93^{\mathrm{a}}$ & 11.21 to 12.65 & $<0.0001$ \\
\hline Analysis 2 & $6.37^{\mathrm{a}}$ & 5.75 to 6.99 & $<0.0001$ \\
\hline Analysis 3 & $9.18^{\mathrm{a}}$ & 8.52 to 9.83 & $<0.0001$ \\
\hline
\end{tabular}

Note: Analysis 1 covers two years of study period when co-payment in Wales was $£ 6$ and $£ 4$. Analysis 2 covers two years study period when co-payment in Wales was $£ 4$ and $£ 3$. Analysis 3 covers two years study period when co-payment in Wales was $£ 3$ and $£ 0$. ${ }^{\text {a }}$ Monthly number of items dispensed per practice per 1000 population. "Seas 1" (October to December $=1$, else $=0$ ) is a reference category dummy, not included in the model.

Table V. Price elasticity of medicines utilisation in Wales during three study periods

\begin{tabular}{|l|c|c|c|}
\hline & $\begin{array}{c}\text { Percentage change in } \\
\text { medicines utilisation in } \\
\text { Wales }\end{array}$ & $\begin{array}{c}\text { Percentage change in } \\
\text { co-payment in Wales }\end{array}$ & Price elasticity \\
\hline Analysis 1 & $+7.67 \%$ & $-33.39 \%$ & -0.23 \\
\hline Analysis 2 & $+3.38 \%$ & $-25.06 \%$ & -0.13 \\
\hline Analysis 3 & $+4.54 \%$ & $-100.0 \%$ & -0.04 \\
\hline
\end{tabular}

Note: Analysis 1 covers two years of study period when co-payment in Wales was $£ 6$ and $£ 4$. Analysis 2 covers two years study period when co-payment in Wales was $£ 4$ and $£ 3$. Analysis 3 covers two years study period when co-payment in Wales was $£ 3$ and $£ 0$. 